\title{
Chemical Composition of Teas from Two Cultivated Chemotypes of Egletes viscosa ("Macela-da-terra")
}

\author{
Gizelle Angela B. Vieira, ${ }^{a}$ Mary Anne S. Lima, ${ }^{a}$ Antonio Marcos E. Bezerra ${ }^{b}$ \\ and Edilberto R. Silveira*,a \\ ${ }^{a}$ Curso de Pós-Graduação em Química Orgânica, Departamento de Química Orgânica e Inorgânica, Centro de \\ Ciências, Universidade Federal do Ceará, CP 12200, 60451-970 Fortaleza-CE, Brazil \\ ${ }^{b}$ Departamento de Fitotecnia, Universidade Federal do Ceará, CP 12168, 60356-760 Fortaleza-CE, Brazil
}

\begin{abstract}
A análise fitoquímica das infusões das inflorescências de dois quimiotipos cultivados de Egletes viscosa Less foi realizada. O novo diterpeno 12-acetoxi-7-hidroxi-3,13(14)clerodandieno-18,19:15,16-diolídeo, ternatina, ácido centipédico e a lactona do ácido 12-acetoxihawtriwaico foram isolados a partir do quimiotipo acetato de trans-pinocarveíla, enquanto que o quimiotipo acetato de cis-isopinocarveíla forneceu o 12-acetoxi-7-hidroxi-3,13(14)clerodandieno-18,19:15,16-diolídeo, 12-epi-bacchotricuneatina, ternatina e escopoletina. A elucidação estrutural dos compostos isolados foi realizada com base em dados espectrais, através do uso de seqüências de pulsos de RMN uni e bidimensionais e comparação com dados da literatura.
\end{abstract}

Phytochemical analysis of flower buds infusion from two cultivated chemotypes of Egletes viscosa Less was accomplished. The new diterpene 12-acetoxy-7-hydroxy-3,13(14)clerodandien-18,19:15,16-diolide, ternatin, centipedic acid and 12-acetoxy-hawtriwaic lactone were isolated from the chemotype trans-pinocarveyl acetate. Analysis of the chemotype cisisopinocarveyl acetate yielded 12-acetoxy-7-hydroxy-3,13(14)-clerodandien-18,19:15,16diolide, 12-epi-bacchotricuneatin, ternatin and scopoletin. Structural elucidation of the isolated compounds was established on the basis of spectral data through the use of 1D NMR and several 2D shift correlated NMR pulse sequences and comparison with literature data.

Keywords: Egletes viscosa chemotypes, trans-pinocarveyl acetate, cis-isopinocarveyl acetate, infusion chemical constitution

\section{Introduction}

Egletes viscosa Less (Asteraceae) is an annual herb mostly native to intertropical Americas that grows throughout the northeast of Brazil at the margins of river and lakes as soon as the raining season ends. It is popularly known as "macela" or "marcela", and sometimes as "macela-da-terra" to differentiate it from Achyrocline satureoides, other Asteraceae common at the south and southeast regions of Brazil. Due to its large household use for the preparation of a tea to which emmenagogue, diaphoretic, ${ }^{1}$ stomachic and antidiarrhoea ${ }^{2}$ properties seem to be related, dried flower buds of Egletes viscosa are widely sold in herbal stores and supermarkets of the Brazilian northeast.

*e-mail: edil@ufc.br
During the last decade, phytochemical, pharmacological and agronomic studies of Egletes viscosa have been performed in our research group. Previous works with the flower buds purchased from a herbal store in Fortaleza, Ceará, allowed to obtain an essential oil characterized by trans-pinocarveyl acetate $\mathbf{1}$ as the major constituent. ${ }^{3}$ From the non-volatile fraction ternatin 2, and the diterpenes centipedic acid $\mathbf{3}$, barbatol 4, tarapacol $\mathbf{5}$, and 12-acetoxy-hawtriwaic lactone $\mathbf{6}$ were isolated. ${ }^{3,4}$ The pharmacological studies showed anti-hepatotoxic, ${ }^{5}$ antiperoxidative, ${ }^{6}$ gastroprotective and antidiarrhoeal, ${ }^{7}$ hepatoprotective, ${ }^{8}$ antithrombotic, ${ }^{9}$ anti-anaphylactic and anti-inflammatory ${ }^{10,11}$ properties for ternatin 2; antinociceptive and gastroprotective for the diterpenes $\mathbf{3}$ and $\mathbf{6},{ }^{12}$ and antinociceptive, anticonvulsant and antibacterial activities for the essential oil, ${ }^{13}$ in agreement with the ethnobotanical use of this plant. 
Further, extensive studies were performed with essential oils from flower buds of specimens harvested from different collection sites in Ceará, and the occurrence of a new chemotype characterized by high contents of the new monoterpene cis-isopinocarveyl acetate 7 was observed. ${ }^{4}$

Based on these previous findings, agronomic studies were addressed to the establishment of a sustainable production of the two chemotypes of E. viscosa, aiming to determine and compare their chemical profile. Studies of the phenology, asexual and vegetative propagation by seeds, organic fertilization and crop harvesting allowed the development of system of production for E. viscosa, and consequently the availability of the flower buds from both cultivated chemotypes. Thus, the phytochemical studies were directed to the analysis of the lyophilized teas from both flower buds chemotypes. The transpinocarveyl chemotype gave ternatin 2 , centipedic acid 3, 12-acetoxy-hawtriwaic lactone 4 and the new 12acetoxy-7-hydroxy-3,13(14)-clerodandien-18,19:15,16diolide 8. From the cis-isopinocarveyl chemotype the same diterpene 8, 12-epi-bacchotricuneatin 9 and scopoletin $\mathbf{1 0}$ were isolated, in addition to ternatin $\mathbf{2}$.

\section{Results and Discussion}

Compound $\mathbf{8}$ was obtained as a yellow amorphous solid, mp $109.8-111.2{ }^{\circ} \mathrm{C}$. Its molecular formula $\mathrm{C}_{22} \mathrm{H}_{28} \mathrm{O}_{7}$ was determined by mass spectrometry ([M] $]^{+}$ $\mathrm{m} / \mathrm{z}$ 404) in addition to the NMR data. The IR spectrum displayed diagnostic absorption bands referring to hydroxyl groups at 3472 and two $\gamma$-lactone carbonyls at 1778 and $1752 \mathrm{~cm}^{-1} \cdot{ }^{14}$ The ${ }^{13} \mathrm{C}$ NMR spectrum displayed 22 signals associated with three methyl groups ( $\delta$ 12.6, 19.4 and 21.5), six methylenes and six methines, two of wich were axygenated $(\delta 67.2$ and 72.3$)$, and two olefinic ( $\delta 116.5$ and 135.2). In addition, seven non-hydrogenated carbons including three ester carbonyls ( $\delta$ 170.3, 170.2 and 173.3) were observed. These data allowed to deduce the skeleton of $\mathbf{8}$ as a clerodane diterpene, which contained one extra acetoxy moiety.

The ${ }^{1} \mathrm{H}$ NMR spectrum revealed signals consistent with the presence of an angular methyl at $\delta 0.93\left(\mathrm{~s}, \mathrm{CH}_{3}-\right.$ 20), a tertiary methyl group at $\delta 1.08\left(\mathrm{~d}, J 6.9 \mathrm{~Hz}, \mathrm{CH}_{3}-\right.$ $17)$, an acetyl methyl at $\delta 2.16\left(\mathrm{~s}, \mathrm{OCOCH}_{3}\right)$, an oxymethine at $\delta 4.17$ (q, $J 2.7, \mathrm{H}-7$ ), an acylated carbinolic methine at $\delta 5.74(\mathrm{~d}, J 9.2 \mathrm{~Hz}, \mathrm{H}-12)$ and two olefinic methines at $\delta 6.73(\mathrm{dd}, J 7.2$ and $1.8 \mathrm{~Hz}, \mathrm{H}-3)$ and 6.00 (s, H-14), respectively. By analyzing the ${ }^{1} \mathrm{H}-{ }^{1} \mathrm{H}$ COSY spectrum, it was observed two AB systems for oxygenated carbons bearing diastereotopic hydrogens as two pairs of doublets at $\delta 5.37 / 3.93$ (2H-19) and $\delta 4.80 /$ 4.92 (2H-16), consistent with oxymethylene hydrogens of two $\gamma$-lactone rings observed previously in the IR. In the same way, vicinal couplings between the hydrogen at $\delta 1.81(\mathrm{H}-10)$ with the hydrogen at $\delta 1.25\left(\mathrm{H}_{\mathrm{ax}}-1\right)$, were observed whereas the latter showed correlation with the hydrogens at $\delta 2.11\left(\mathrm{H}_{\mathrm{ax}}-2\right)$ and $2.47\left(\mathrm{H}_{\mathrm{eq}}-2\right)$ which in turn coupled with the olefinic hydrogen at $\delta 6.73(\mathrm{H}-3)$. In this analysis all the coupled proton systems were obtained, and the fragment $-\mathrm{CH}-\mathrm{CH}_{2}-\mathrm{CH}_{2}-\mathrm{CH}=\mathrm{C}$ was deduced.

The proposed assignment for the clerodane skeleton was supported by the HMBC spectrum through longrange correlations of both methyl groups at $\delta 0.93(\mathrm{H}-$ 20) and 1.08 (H-17) with the carbon at $\delta 39.8$ (C-9). The relatively downfield position of the oxymethine hydrogen at $\delta 5.74(\mathrm{H}-12)$ was in agreement with the presence of an acetoxy group at $\mathrm{C}-12$ on the basis of the its correlations with the carbons at $\delta 39.8$ (C-9) and 41.6 (C-11), and with the carbons relative to an $\alpha, \beta$ unsaturated $\gamma$-lactone moiety in the side chain at $\delta 70.6$ (C-16), 116.5 (C-14) and 168.9 (C-13). Correlations of the olefinic hydrogen at $\delta 6.00(\mathrm{H}-14)$ with the carbons at $\delta 67.2$ (C-12), 70.9 (C-16), 168.9 (C-13) and the carbonyl at $\delta 173.3$ (C-15), proved this assumption. Furthermore, correlations of both oxymethylene hydrogens at $\delta 3.93(\mathrm{H} \alpha-19)$ and $5.37(\mathrm{H} \beta-19)$ with the carbons at $\delta 40.6$ (C-6), 49.8 (C-10), 139.4 (C-4) and 170.2 (C-18) confirmed the presence of an 18,19 lactone function. Figure 1 depicts several key long-range correlations observed through the HMBC experiment.

The localization of the hydroxyl group at C-7 was deduced by correlations of the oxymethine hydrogen at $\delta$

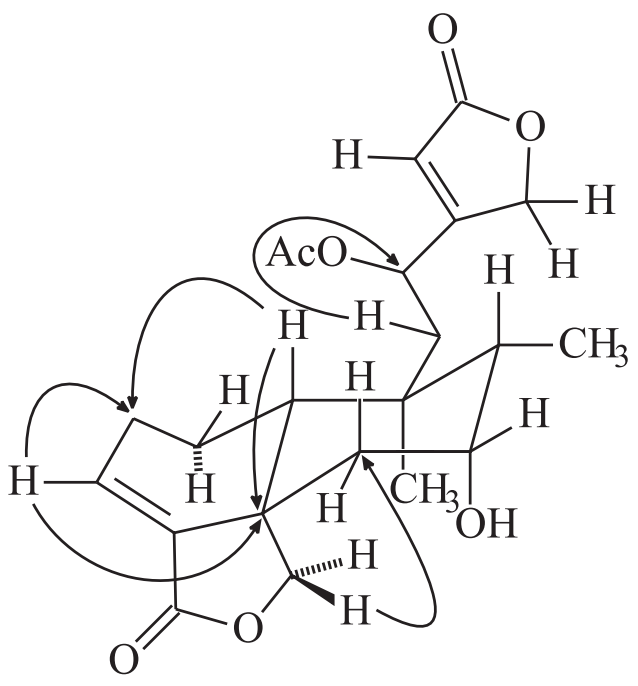

Figure 1. Key HMBC long-range correlations observed in the HMBC spectrum of $\mathbf{8}$. 
4.17 (H-7) with the carbons at $\delta 39.8$ (C-9) and 45.4 (C-5). Its stereochemical configuration was definitively determined on the basis of the highfield signal for $\mathrm{H} \beta-19$ at $\delta 5.37$ that could be attributed to its $\beta$-orientation within the 18,19 lactone ring, since that this hydrogen could be affected by the presence of the axial hydroxyl group at C-7. This was supported by the presence of a $4 \sigma$-coupling ( $w$-coupling) for the $\mathrm{H} \alpha-19$ at $\delta 3.93$ with $\mathrm{H}-10$, typical of clerodane diterpenes containing 18,19-lactone ring. ${ }^{15}$ In particular, NOESY correlations between $\mathrm{H} \alpha-19(\delta 3.93)$ with the $\mathrm{H}_{\mathrm{eq}}-7$ ( $\delta$ 4.17) and of the $\mathrm{H} \beta-19(\delta 5.37)$ with the $\mathrm{CH}_{3}-20(\delta 0.93)$ confirmed these assignments unambiguously. Figure 2 shows some key dipole-dipole interactions observed through the NOESY experiment.

The NMR data published for kerlinolide 11, isolated from Salvia keerlii (Labiatae), were found to be a good model for comparison. ${ }^{16}$ In this work, the relative position

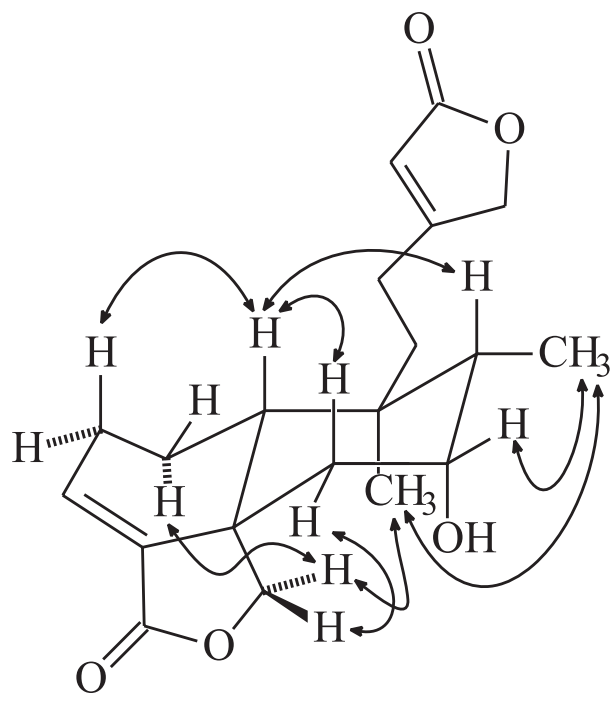

Figure 2. Key dipole-dipole interactions observed in the NOESY spectrum of $\mathbf{8}$.

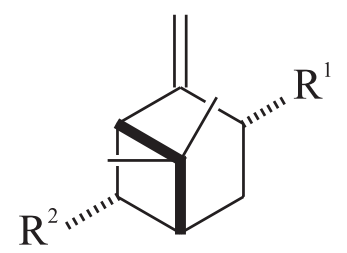

$1 \mathrm{R}^{1}=\mathrm{OAc}, \mathrm{R}^{2}=\mathrm{H}$

$7 \mathrm{R}^{1}=\mathrm{H}, \mathrm{R}^{2}=\mathrm{OAc}$<smiles>[CH]c1cc(OC)c(OC)c2oc(-c3ccc(O)c(OC)c3)c(OC)c(=O)c12</smiles><smiles>CC1(C)CCC[C@]2(C)C1CC[C@]1(C)O[C@@](C)([C@@H](O)CO)CCC12</smiles><smiles>CC(C)OC(C[C@@]1(C)C2CCC=C3C(=O)OC[C@@]32CC[C@@H]1C)c1ccoc1</smiles>

6

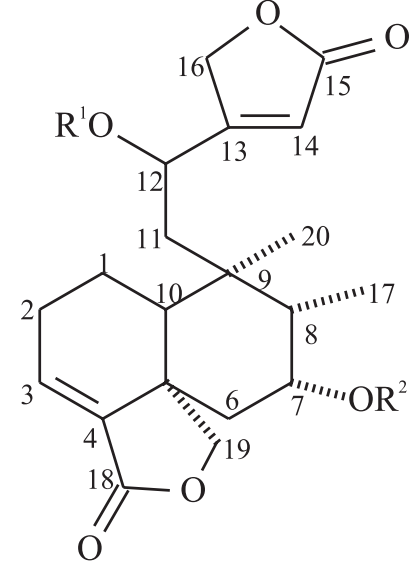

$8 \mathrm{R}^{1}=\mathrm{Ac}, \mathrm{R}^{2}=\mathrm{H}$

$11 \mathrm{R}^{1}=\mathrm{H}, \mathrm{R}^{2}=\mathrm{Ac}$<smiles>C[C@]12C[C@@H](c3ccoc3)OC(=O)[C@@H]1CC[C@@]13COC(=O)C1=CCCC32</smiles>

9 
of the acetoxy and hydroxyl groups are interchanged, although its ${ }^{13} \mathrm{C}$ NMR data are almost identical to compound 8. However, detailed HMBC analysis definitively supported the proposed structure of $\mathbf{8}$ as the new 12-acetoxy-7 $\beta$ hydroxy-3,13(14)-clerodien-18,19:15,16-diolide.

At this point it is important to make some considerations related to the ethnobotanical use of Egletes viscosa. From our findings we can conclude that: the infusion of the flower buds of any chemotype of E. viscosa can present common constituents ( $\mathbf{2}$ and $\mathbf{8}$ ), others of similar composition but different constitution ( $\mathbf{1}$ versus 7; 6 versus 9), and completely different components restricted to each chemotype (3 and 10); both chemotypes are available commercially either alone or in mixture; the effectiveness of both chemotypes in the alleged action of its folklore use to treat gastric problems, will remain as a challenging field for scientists to unveil the relationship between the chemical constitution and the pharmacological action of these traditional remedies with household use in nowdays.

\section{Experimental}

\section{General procedures}

Melting points (uncorrected) were obtained on a Mettler FP82HT. IR spectra were recorded using a Perkin Elmer 1000 spectrophotometer. Optical rotations were measured on a Perkin Elmer 341 polarimeter. The mass spectra were obtained on a Hewlett-Packard 5971 mass spectrometer by electron impact ionization $(70 \mathrm{eV}) .{ }^{1} \mathrm{H}$ and ${ }^{13} \mathrm{C}$ NMR where recorded on a Bruker Avance DRX500 ; chemical shifts are given in $\delta$ (ppm) relative to TMS as an internal standard. All compounds were visualized on TLC using the vanillin-sulfuric acid reagent.

\section{Plant material}

Cultivated flower buds of Egletes viscosa Less chemotypes were harvested from garden beds at the Departamento de Fitotecnia of the Universidade Federal do Ceará, Fortaleza, Ceará State. Voucher specimens (36693 and 36694) have been identified by Dr. Edson Paula Nunes and deposited at the Herbário Prisco Bezerra (EAC), Departamento de Biologia, Universidade Federal do Ceará, Brazil.

\section{Extraction and isolation}

$200 \mathrm{~g}$ aliquots of ground flower buds of Egletes viscosa chemotype trans-pinocarveyl acetate were extracted by infusion with $1.0 \mathrm{~L}$ boiling water $(2 \times)$. This procedure
Table 1. NMR spectral data for diterpene $\mathbf{8}\left(\mathrm{CDCl}_{3}\right)$

\begin{tabular}{|c|c|c|}
\hline Carbon & $\delta_{\mathrm{C}}$ & $\delta_{\mathrm{H}}$ \\
\hline 1 & 20.3 & $\begin{array}{l}1.25 \mathrm{ddd}(J 12.1,7.6,3.7 \mathrm{~Hz}) \\
2.10 \mathrm{~m}\end{array}$ \\
\hline 2 & 27.8 & $\begin{array}{l}2.47 \mathrm{~d} \mathrm{~m}(J 16.0 \mathrm{~Hz}) \\
2.11 \mathrm{~d} \mathrm{~m}(J 16.0 \mathrm{~Hz})\end{array}$ \\
\hline 3 & 135.2 & $6.73 \mathrm{dd}(J 7.2,1.8 \mathrm{~Hz})$ \\
\hline 4 & 139.4 & \\
\hline 5 & 45.4 & \\
\hline 6 & 40.6 & $\begin{array}{l}1.42 \mathrm{dt}(J 14.1,2.2 \mathrm{~Hz}) \\
2.36 \mathrm{dd}(J 14.1,2.2 \mathrm{~Hz})\end{array}$ \\
\hline 7 & 72.3 & $4.17 \mathrm{q}(J 2.7 \mathrm{~Hz})$ \\
\hline 8 & 41.5 & $1.70 \mathrm{~m}$ \\
\hline 9 & 39.8 & \\
\hline 10 & 49.8 & $1.81 \mathrm{~d}(J 4.2 \mathrm{~Hz})$ \\
\hline 11 & 41.6 & $\begin{array}{l}1.69 \mathrm{dd}(J 16.2,2.1 \mathrm{~Hz}) \\
2.18 \mathrm{dd}(J 16.2,9.2 \mathrm{~Hz})\end{array}$ \\
\hline 12 & 67.2 & $5.74 \mathrm{~d}(J 9.2 \mathrm{~Hz})$ \\
\hline 13 & 168.9 & \\
\hline 14 & 116.5 & $6.00 \mathrm{~s}$ \\
\hline 15 & 173.3 & \\
\hline 16 & 70.9 & $\begin{array}{l}4.80 \mathrm{dd}(J 17.6,1.5 \mathrm{~Hz}) \\
4.92 \mathrm{dd}(J 17.6,1.5 \mathrm{~Hz})\end{array}$ \\
\hline 17 & 12.6 & $1.08 \mathrm{~d}(J 6.9 \mathrm{~Hz})$ \\
\hline 18 & 170.2 & \\
\hline 19 & 73.0 & $\begin{array}{l}5.37 \mathrm{~d}(J 7.8 \mathrm{~Hz}) \\
3.93 \mathrm{dd}(J 7.8,1.8 \mathrm{~Hz})\end{array}$ \\
\hline 20 & 19.4 & $0.93 \mathrm{~s}$ \\
\hline $\mathrm{OCOCH}_{3}$ & 170.3 & \\
\hline $\mathrm{OCOCH}_{3}$ & 21.5 & $2.16 \mathrm{~s}$ \\
\hline
\end{tabular}

was repeated five times. Lyophilization of the water soluble resultant yielded $47.2 \mathrm{~g}$ of a brown powder from a total of $1.0 \mathrm{~kg}$ of flower buds. The tea extract was stirred with $\mathrm{CH}_{2} \mathrm{Cl}_{2}(50 \mathrm{~mL})$ for $30 \mathrm{~min}(5 \times)$, followed by $\mathrm{MeOH}$ and finally with $\mathrm{H}_{2} \mathrm{O}$ to yield $3.5,16.2$ and $26.4 \mathrm{~g}$, respectively, after solvent evaporation and lyophilization. Successive flash chromatography of the $\mathrm{CH}_{2} \mathrm{Cl}_{2}$ fraction using hexane: $\mathrm{CHCl}_{3}$ as a binary mixture with increasing polarity, yielded compounds $\mathbf{2}(64.0 \mathrm{mg})$ and $\mathbf{3}(8.0 \mathrm{mg})$, $4(5.0 \mathrm{mg})$ and $\mathbf{8}(61.0 \mathrm{mg})$.

The infusions from flower buds of the chemotype cisisopinocarveyl acetate $(1.0 \mathrm{~kg})$ gave $50.0 \mathrm{~g}$ of a dark brown powder after lyophilization. Applying the same procedure of solvent extraction for the tea extract afforded three fractions: $\mathrm{CH}_{2} \mathrm{Cl}_{2}(3.06 \mathrm{~g}), \mathrm{MeOH}(12.6 \mathrm{~g})$ and $\mathrm{H}_{2} \mathrm{O}(21.8$ g). Flash chromatography of the $\mathrm{CH}_{2} \mathrm{Cl}_{2}$ fraction using hexane: $\mathrm{CHCl}_{3}$ as a binary mixture with increasing polarity afforded six fractions after TLC comparison. From the F-6 fraction compound 8 was obtained $(5.4 \mathrm{mg})$. Treatment of the F-4 fraction on Sephadex LH-20 and elution with $\mathrm{MeOH}$ gave the pure compounds $2(4.0 \mathrm{mg}), \mathbf{9}(23.0 \mathrm{mg})$ and $\mathbf{1 0}(7.3 \mathrm{mg})$.

12-Acetoxy-7 $\beta$-hydroxy-3,13(14)-clerodandien18,19:15,16-diolide, (8). Yellowish amorphous solid; 
$[\alpha]_{\mathrm{D}}^{20}-126.0^{\circ}\left(\mathrm{CHCl}_{3} ; c 0.02\right)$; IR (film) $v_{\max } / \mathrm{cm}^{-1}: 3472$, 2935, 2883, 1778, 1752, 1655, 1641, 1434, 1373, 1288, 1230, 1192, 1126, 1040, 990, 964, 889; EIMS m/z (rel. int.): $404\left[\mathrm{M}^{\dagger}\right](7), 385$ (8), 374 (12), 357 (35), 344 (10), 314(25), 234 (21), 217(32), 201 (42), 177 (38), 159 (37), 145 (12), 131 (38), 114 (46), 91 (50), 79 b(41), 67 (35), 43 (100), 41 (31). ${ }^{1} \mathrm{H}$ and ${ }^{13} \mathrm{C}$ NMR: Table 1.

\section{Acknowledgments}

The authors are grateful to CNPq/CAPES/PADCT/ PRONEX/FUNCAP/FINEP for the fellowships and financial support.

\section{References}

1. Braga, R.; Plantas do Nordeste, Especialmente do Ceará, Imprensa Oficial: Fortaleza, Brazil, 1960.

2. Correia, P.; Dicionário de Plantas Úteis do Brasil e das Exóticas Cultivadas, Instituto Brasileiro de Desenvolvimento Florestal: Rio de Janeiro, Brasil, 1984.

3. Lima, M. A. S.; Silveira, E. R.; Marques, M. S. L.; Santos, R. H. A.; Gambardela, M. T. P.; Phytochemistry 1996, 41, 217.

4. Cunha, A. N.; PhD. Thesis, Universidade Federal do Ceará, Brazil, 2003.

5. Rao, V. S. N.; Figueiredo, E. G.; Melo, C. L.; Viana, G. S. B.; Menezes, D. B.; Matos, M. S. F.; Silveira, E. R.; Pharmacology 1994, 48, 392.

6. Souza, M. F.; Rao, V. S. N.; Silveira, E. R.; Phytomedicine 1997, 4, 27.
7. Rao, V. S. N.; Santos, F. A.; Sobreira, T. T.; Souza, M. F.; Melo, C. L.; Silveira, E. R.; Planta Med. 1997, 63, 146.

8. Souza, M. F.; Rao, V. S. N.; Silveira, E. R.; Phytother. Res. 1998, 12, 557.

9. Souza, M. F.; Cunha, G. M. A.; Fontenele, J. B.; Viana, G. S. B.; Rao, V. S. N.; Phytother. Res. 1994, 8, 478.

10. Souza, M. F.; Rao, V. S. N.; Silveira, E. R.; Braz. J. Med. Biol. Res. 1992, 25, 1029

11. Rao, V. S. N.; Paiva, L. A. F.; Souza, M. F.; Campos, A. R.; Ribeiro, R. A.; Brito, G. A. C.; Teixeira, M. J.; Silveira, E. R.; Planta Med. 2003, 69, 851.

12. Guedes, M. M.; Cunha, A. N.; Silveira, E. R.; Rao, V. S. N.; Planta Med. 2002, 68, 1042.

13. Souza, M. F.; Santos, F. A.; Rao, V. S. N.; Sidrim, J. J. C.; Matos, F. J. A.; Machado, M. I. L.; Silveira, E. R.; Phytother. Res. 1998, 12, 28.

14. Levy, G.; Lichter, R. L.; Nelson, G. L.; Carbon-13 Nuclear Magnetic Resonance Spectroscopy, $2^{\text {nd }}$ ed., Wiley \& Sons: New York, 1980.

15. Fernandez, D. C.; Esquivel, B.; Cardenas, J.; Sanchez, A. A.; Toscano, R. A.; Rodriguez-Hahn, L.; Tetrahedron 1991, 47, 7199.

16. Esquivel, B.; Méndez, A.; Ortega, A.; Soriano-Garcia, M.; Toscano, A.; Rodriguez-Hahn, L.; Phytochemistry 1985, 24, 1769.

Received: June 6, 2005 Published on the web: November 18, 2005 